ARAȘTIRMA / RESEARCH ARTICLE

\title{
Elektrik Yaralanması Nedeniyle Başvuran Çocukların Klinik, Demografik Özellikleri ve Klinik Sonucu Etkileyen Faktörler: Tek Merkez Çocuk Acil Kliniği Deneyimi
}

\section{Clinical, Demographic Characteristics and Factors Affecting the Clinical Outcome of Children with Electrical Injury: A Single-Center Pediatric Emergency Clinic Experience}

Emel Ataş Berksoy, Selçuk Yazıc1*

\section{$\ddot{O} \mathbf{z}$}

Amaç: Bu çalışmada çocukluk çağı elektrik yaralanmalarının demografik ve klinik özelliklerinin belirlenmesi, klinik sonucu etkileyen faktörlerin saptanması amaçlanmıştır.

Gereç ve Yöntem: Ocak 2008- Aralık 2015 tarihleri arasında elektrik yaralanması nedeniyle acil servise başvuran 112 hastanın dosya verileri geriye dönük incelenmiştir. Olgular 5 yaş ve altı, 6-10 yaş arası ile 10 yaş ve üstü olarak üç gruba ayrılarak elektrik kaynağı ve gücü, yaralanmanın oluş şekli, izlem yeri, klinik yakınmalar ve laboratuvar değerleri açısından gruplar arası ilişki incelenmiştir.

Bulgular: Hastaların 78'i (\%69,6) erkek, 34'ü $(\% 30,4)$ kız olup ortanca yaş 5 y1l (11 ay-15 yıl) idi. Hastaların 101'i $(\% 90,2)$ düşük voltajlı akım ile 88'i $(\% 78,6)$ ev içi ortamda yaralanmıştı. Elektrik kaynağına göre altı yaş altında en sık prizlerin $(\% 67,9), 6-10$ yaş arasında elektrik kablosunun $(\% 39,4), 10$ yaş ve üstü grupta elektrikli ev aletlerinin $(\% 41,6)$ neden olduğu görüldü. İki hastada sinüs bradikardisi, dört hastada firlatılmaya bağlı yumuşak doku travması vardı. Hiçbir hastada derin doku hasarı, ileri derecede yanık ve böbrek yetmezliği gözlenmedi. Troponin I, karaciğer ve böbrek fonksiyon testleri, serum elektrolitleri, lökosit düzeyleri hastaların tamamında normaldi.

Sonuç: Çocuklarda elektrik yaralanmaları çoğunlukla önlenebilir ev içi düşük voltajlı akım ile gerçeklemiştir. Başvuru anında bilinci açık, derin doku hasarı ve disritmisi olmayan düşük voltajlı elektrik yaralanmalarında ileri incelemeler gerekmeyebilir.

Anahtar Kelimeler: Elektrik Yaralanmaları; Çocuk; Travma.

\section{Abstract}

Objective: The aim of this study was to determine the demographic and clinical characteristics of childhood electrical injuries and to determine the factors affecting clinical outcome.

Materials and Methods: The data of 112 patients who applied to the emergency department between January 2008 and December 2015 were retrospectively analyzed. The patients were divided into three groups as under 6 years of age, 6 to 10 years old and 10 years of age and over, and the relationship between the groups in terms of electricity supply and voltage, the occurrence of injury, clinical complaints and laboratory values were examined.

Results: $78(69.6 \%)$ of the patients were male and $34(30.4 \%)$ were female. The median age was 5 years (11 months- 15 years). 101 of the patients $(90.2 \%)$ had injured with low-voltage current and $88(78.6 \%)$ were injured in the house environment. According to the electrical source, the most frequent causes of injury were plug sockets under the age of six years $(67.9 \%)$, electrical cable between the ages of six to ten years (39.4\%), electrical devices over ten years of age (41.6\%). Two patients had sinus bradycardia and four patients had soft tissue trauma due to fall. None of the patients had deep tissue damage, severe burn and renal failure. Troponin I, liver and kidney function tests, serum electrolytes, leukocyte levels were normal in all patients.

Conclusion: The majority of electrical injuries in children were due to low voltage current and preventable household contact. Further investigations may not be required in low-voltage electrical injuries with no loss of consciousness, no deep tissue damage and no dysrhythmia at the time of admission.

Keywords: Electrical Injury; Child; Trauma.
DOI: $10.17986 / \mathrm{blm} .2019149813$

Emel Ataş Berksoy: Uzm. Dr., İzmir Sağlık Bilimleri Üniversitesi Tepecik Eğitim ve Araştırma Hastanesi, Çocuk Acil Kliniği, İzmir Eposta: emelberksoy@hotmail.com ORCID iD: https://orcid.org/00000002-6831-1353

Selçuk Yazıcı: Dr. Öğr. Üyesi, Balıkesir Üniversitesi Tıp Fakültesi, Çocuk Sağlığı ve Hastalıkları Anabilim Dalı, Balıkesir

Eposta: selcuk.yzci@gmail.com ORCID iD: https://orcid.org/00000002-6526-9460

\section{Bildirimler:}

Yazarlar bu makale ile ilgili herhangi bir çıkar çatışması bildirmemişlerdir. Geliş: 11.01.2019

Kabul: 13.02.2019

p-ISSN: $1300-865 \mathrm{X}$

e-ISSN: 2149-4533 


\section{Giriş}

Elektrik yaralanmaları (EY) elektriğin yaygın olarak kullanımına bağlı olarak dünyada tüm ülkeler için hala bir sorun oluşturmaktadır. EY nadiren de olsa vücutta birçok sistemi etkileyebileceğinden yüksek morbidite ve mortalite ile ilişkilidir (1). Bildirilmeyen EY olgularından dolayı gerçek insidansı tahmin etmek zordur. Gelişmiş ülkelerde EY bağlı mortalitenin ana nedeni yüksek voltajlı elektrik akımına bağlı iş kazaları ve yıldırım çarpmalarıdır. ABD'de her yıl yaklaşık EY nedeniyle 1500 ölüm görülürken bu oranın \%10 kadarını çocuklar oluşturmaktadir (2).

EY küçük cilt yanıklarından yaşamı tehdit eden organ yaralanmalarına kadar değişen geniş bir klinik çeşitliliğe sahiptir. Yaralanmanın şiddeti maruz kalınan elektrik akımının cinsine (doğru/ alternatif), yoğunluğuna (amper), akıma maruz kalma süresine, akımın vücutta izlediği yola ve akıma maruz kalan bölgenin direncine (nemli cilt, mukoza, iç organlar) bağlı olarak değişir $(3,4)$. Yüksek voltajlı $(\geq 1000 \mathrm{~V})$ kazalar çoğunlukla iş kazaları nedeniyle olup özellikle erkeklerde görülürken düşük voltajlı yaralanmalar $(<1000 \mathrm{~V})$ daha çok ev içi kazalara bağlı olarak çocuk ve kadınlarda görülmektedir. EY'nın önemli bir kısmı düşük voltajlı ev içi kazaları ile olmaktadır (5). Bu durum çoğunlukla çocuklarda görülmekte ve bu çocukların hemen hepsi çocuk acil servislere başvurmaktadırlar. Kardiyovasküler sistem, iskelet kas1, sinir sistemi, böbrekler ve cilt en sık etkilenen bölgeler olmakla beraber EY da ilk ölüm nedeni kalp durmasıdır. Kalbe olan ilk ciddi etkileri maruziyetin hemen sonrasında oluşmasına rağmen, özellikle düşük voltajlı EY ile başvuran hastaların yaralanma sonrası monitörlü izlemlerinin gerekliliği ve/veya ideal izlem süreleri tartışmalıdır (6-9).

$\mathrm{Bu}$ çalışmada 2008-2015 yılları arasında elektrik çarpması nedeniyle acil servise başvurmuş çocukların demografik, klinik ve laboratuvar özelliklerinin incelenerek, risk faktörleri ve bu faktörlerin sonuçlara etkisinin belirlenmesi, istenen tetkikler ve monitörize izlem gerekliliğinin değerlendirilmesi amaçlandı.

\section{Gereç ve Yöntem}

Bu çalışmada Ocak 2008- Aralık 2015 tarihleri arasında elektrik çarpması sonrası acil servise getirilen 0- 18 yaş aralığında çocuk hastaların dosyaları geriye dönük olarak incelendi. Hastanemiz çocuk acil kliniği çocuk acil ve travma hastası karşılayan (yılda yaklaşık 170000 hasta) bölgedeki üniversite hastaneleri dışında tek referans hastanedir. Çalışma hastanenin yerel etik kurulundan onay alındıktan sonra başlatıldı. Dosya verilerine hastane bilgi işlem sistemi ve adli rapor arşiv sistemi aracılığ 1 ile ulaşıldı. Başvurduğu sırada eşlik eden akut enfeksiyon, kronik hastalığ lar çalışma dışı bırakıldı. Hasta verileri demografik (yaş, cinsiyet), olayın oluş yeri ve elektrik akımının gücü, klinik özellikler (akımın giriş, çıkış yeri, yakınma ve bulgu varlığı, servis ve yoğun bakım yatış durumu ve yatış süresi), laboratuvar sonuçları (beyaz küre, karaciğer ve böbrek fonksiyonları, serum elektrolitleri, Kreatinin Kinaz (CK), Kreatinin Kinaz- Kas/Beyin (CK-MB), Troponin I) ve elektrokardiyogram (EKG) değerlendirilmesi sonucu elde edildi. Hastalar 6 yaş altı ve 6-10 yaş arası ile 10 yaş ve üstü olacak şekilde üç gruba ayrılarak yaş grupları ile demografik veriler, yaralanmanın olduğu yer, elektrik akım gücü ve klinik bulgular arasındaki olası ilişki incelendi.

İstatistiksel incelemede "SPSS ver.22 for Windows" programı ile tanımlayıcı istatistikler kullanıldı. Yaş grupları arasındaki parametrelerin karşılaştırılması One Way Anova testi ile incelendi. Nitelik belirten veriler sıklık ve yüzde değerleri ile, laboratuvar sonuçları ortalama \pm standart sapma şeklinde sunuldu.

\section{Bulgular}

Belirtilen zaman diliminde 138 hasta EY nedeniyle başvurdu. 26 hastanın bir kısmı dosya verilerine ulaş1lamaması bir kısmı da başvuru anında akut enfeksiyonları olmaları nedeniyle çalışma dışı bırakıldı. Çalışmaya alınan toplam 112 hastanın 78'i $(\% 69,6)$ erkek, 34'ü $(\% 30,4) \mathrm{kız}$, yaş ortancaları 5 yıl $(11$ ay-15 yıl) idi. Yaş gruplarına göre ayrıldığında hastaların 55'i $(\% 49,1)) 6$ yaş altında, 35'i (\%31,3) 6-10 yaş aralığı, 22'si $(\% 19,6)$ 10 yaş ve üstünde idi.

Kazaların 88'inin $(\% 78,6)$ evde olduğu saptandı. Olguların 53'ünün $(\% 47,3)$ prize parmak veya yabancı cisim sokma, 33'ünün $(\% 29,5)$ elektrik kablosu tutma sonucu yaralandığı görüldü. Düşük voltaj $(<1000 \mathrm{~V})$ ile yaralanma $101(\% 90,2)$ hastada, yüksek voltaj $(\geq 1000 \mathrm{~V})$ ile yaralanma ise 11 hastada $(\% 9,8)$ saptandı. Yüksek gerilim hattı kablo, elektrik direği, trafo ile ilişkili kazaların yüksek voltajlı EY olarak kabul edildiği görüldü. Olguların 89'unda $(\% 79,5)$ elektrik giriş yeri, 35 'inde $(\% 31,2)$ elektrik çıkış yerine ait cilt yanığ lezyonu tespit edildi. Giriş lezyonların çoğunluğu $(\% 74,1)$ elde ve parmaklarda olup ileri tedavi gerektirmeyen birinci derece yanıklardı (Tablo 1).

Hastaların hiçbirinde başvuru anında bilinç kaybı saptanmadı. Olguların 90'nda $(\% 80,4)$ yakınma ve bulgu yok iken olay yerinde bilinç kaybı ve senkop $6(\% 5,4)$, çarpma sonrası firlatılma $4(\% 3,6)$, nöbet $1(\% 0,9)$ hastada görüldü. EKG hastaların ikisi hariç hepsine çekildi ve sadece iki hastada $(\% 1,8)$ sinüs bradikardisi dışında 
Tablo 1. EY nedeniyle çocuk acil kliniğine başvuran hastaların yaş gruplarına göre demografik özellikleri

\begin{tabular}{|c|c|c|c|c|c|c|c|c|c|}
\hline & $\begin{array}{c}\text { Toplam hasta } \\
\text { (n) }\end{array}$ & $\%$ & $0-5$ yaş $(n)$ & $\%$ & 6-10 yaş (n) & $\%$ & $\geq 10$ yaş $(n)$ & $\%$ & p \\
\hline $\mathrm{n}$ & 112 & 100 & 55 & 49,1 & 35 & 31,3 & 22 & 19,6 & \\
\hline Erkek/kız & $78 / 34$ & $69,6 / 30,4$ & $38 / 17$ & $69 / 31$ & $24 / 11$ & $68 / 32$ & $16 / 6$ & $72 / 28$ & 0,939 \\
\hline Ev-içi & 88 & 78,6 & & & & & & & \\
\hline Sokak/kapalı alan & $16 / 8$ & $14,3 / 7,1$ & & & & & & & \\
\hline Priz & 53 & 47,3 & 36 & 67,9 & 13 & 24,5 & 4 & 7,5 & \\
\hline Elektrik kablosu & 38 & 33,9 & 12 & 31,5 & 15 & 39,4 & 11 & 28,9 & \\
\hline Elektrikli alet & 12 & 10,7 & 4 & 33,3 & 3 & 25 & 5 & 41,6 & \\
\hline Ampul & 4 & 3,5 & 1 & & 2 & & 1 & & \\
\hline Elektrik direği, trafo & 5 & 4,4 & 2 & & 2 & & 1 & & \\
\hline Düşük voltaj & 101 & 90,2 & 53 & 52,4 & 30 & 29,7 & 18 & 17,8 & 0,086 \\
\hline Yüksek voltaj & 11 & 9,8 & 2 & 18,1 & 5 & 45,4 & 4 & 36,3 & \\
\hline Elektrik giriş yeri + & 89 & 79,4 & 42 & & 29 & & 18 & & \\
\hline Elektrik çıkış yeri + & 35 & 31,2 & 11 & & 17 & & 7 & & \\
\hline
\end{tabular}

normal bulgular tespit edildi. Sinüs bradikardisi olan hastaların maske oksijen tedavisi ile bulguları düzeldi. Hastaların 70'i (\%62,5) acil gözlem odasında en az dört saat kardiyak monitörize edilerek, $21^{\prime} \mathrm{i}(\% 18,8)$ yaşına uygun servislere yatırılarak ( 1 -3 gün) izlendi ve salah ile taburcu edildi. Yüksek voltajlı EY sonrası olay yerinde kardiyak arrest nedeniyle 112 ekibi tarafından müdahale edilerek getirilen bir hasta yoğun bakımda izlendi ve nörolojik sekel ile taburcu edildi (Tablo 2).
Olguların çoğunluğuna olası iç organ hasarı açısından tam kan sayımı (102 hasta), karaciğer (ALT 102, AST 106 hasta) ve böbrek fonksiyon testleri, CK (101 hasta), CK-MB (97 hasta), Troponin I (104 hasta) testleri yapı1d1. Hiçbir hastada beyaz küre sayısı, karaciğer ve böbrek fonksiyonlarında bozukluk saptanmadı. Test edilen tüm CK-MB ve Troponin I düzeyleri normaldi. Yaş gruplar1 arasında laboratuvar parametreleri açısından anlamlı farklılık saptanmadi (Tablo 3).

Tablo 2. EY nedeniyle başvuran hastaların klinik özellikleri

\begin{tabular}{|c|c|c|c|c|c|}
\hline Klinik semptomlar & Toplam hasta (n) & $\%$ & $0-5$ yaş $(n)$ & 6-10 yaş (n) & $\geq 10$ yaş $(n)$ \\
\hline Hasta sayıs1/semptomsuz & $112 / 90$ & 80,3 & $55 / 46$ & $35 / 27$ & $22 / 17$ \\
\hline Bilinç kayb1-senkop & 6 & 5,4 & 3 & 2 & 1 \\
\hline Ağr1 & 6 & 5,4 & 1 & 2 & 1 \\
\hline Firlatılma & 4 & 3,6 & 1 & 1 & 2 \\
\hline Kasılma-nöbet & 1 & 0,9 & 1 & - & - \\
\hline Olduğu yerde kalma & 1 & 0,9 & - & - & 1 \\
\hline Kusma & 2 & 1,8 & - & 2 & - \\
\hline Kardiyakarrest & 1 & 0,9 & - & 1 & - \\
\hline \multicolumn{6}{|l|}{ EKG bulguları } \\
\hline Sinüs bradikardisi & 2 & 1,8 & - & 1 & 1 \\
\hline Normal & 108 & 96,4 & 53 & 34 & 21 \\
\hline \multicolumn{6}{|l|}{ Sonuç-izlem yeri } \\
\hline Acil gözlem (4-12 saat) & 70 & 62,5 & 31 & 21 & 18 \\
\hline Servis yatışı & 21 & 18,8 & 11 & 7 & 3 \\
\hline Ayaktan izlem & 18 & 16,1 & 13 & 5 & - \\
\hline Yoğun bakım yatıș1 & 1 & 0,9 & - & 1 & - \\
\hline
\end{tabular}


Tablo 3. Yaş gruplarına göre laboratuvar sonuçları

\begin{tabular}{|c|c|c|c|c|c|c|}
\hline $\begin{array}{l}\text { Laboratuvar } \\
\text { parametreleri } \\
\text { (n:sayı) }\end{array}$ & $\begin{array}{c}\text { BK }\left(x 10^{3} u / L\right) \\
(n: 106)\end{array}$ & $\begin{array}{c}\operatorname{AST}(U / L)(n: \\
102)\end{array}$ & $\begin{array}{c}\operatorname{ALT}(U / L)(n: \\
106)\end{array}$ & CK(U/L) (n: 101) & $\begin{array}{c}\text { CK-MB (IU/L) } \\
\text { (n: 97) }\end{array}$ & $\begin{array}{c}\text { Troponin } I(\mu g / L)(n: \\
104)\end{array}$ \\
\hline $\begin{array}{c}\text { Tüm hastalar } \\
\text { (Ortalama } \pm \text { SD) }\end{array}$ & $10,3 \pm 3,8$ & $34,8 \pm 16,9$ & $16,4 \pm 6,3$ & $302,12 \pm 613,74$ & $5,08 \pm 9,67$ &, $19 \pm, 92$ \\
\hline $0-5$ yaş & $10,9 \pm 3,7$ & $34,9 \pm 6,2$ & $16,3 \pm 5,0$ & $261,27 \pm 676,23$ & $5,31 \pm 10,49$ & $, 28 \pm 1,28$ \\
\hline $6-10$ yaş & $10,4 \pm 4,6$ & $35,5 \pm 20,2$ & $16,6 \pm 7,2$ & $585,79 \pm 103,55$ & $5,06 \pm 8,14$ &, $16 \pm, 36$ \\
\hline$\geq 10$ yaş & $8,6 \pm 2,3$ & $33,5 \pm 26$ & $16,1 \pm 7,7$ & $527,46 \pm 112,45$ & $4,53 \pm 10,03$ &, $05 \pm, 21$ \\
\hline
\end{tabular}

\section{Tartışma}

EY diğer travma hastaları gibi genç yaş grubunda daha sık görülmektedir. Özellikle 20-30 yaş grubunda erkek oranı \%80-90 kadar iken çocukluk yaş grubunda 2:1 oranında erkekler lehinedir $(10,11)$. Çalışmamızda da EY'nın çocukluk çağında her yaş grubunda (okul öncesi, okul-ergenlik dönemi) yaklaşık $2 / 3$ oranında erkeklerde daha sık olduğu görülmüştür. Erişkinlerdeki bu durum elektrik endüstrisinde çalışan işçilerin çoğunluğun genç erkeklerden oluşması ile açıklanabiliyorsa çocukluk çağında da gerek okul öncesi gerekse ergenlik döneminde olsun erkeklerin kızlara göre daha hareketli ve dürtüsel olma özellikleri ile açılanabilir.

Çalışmamız literatürle uyumlu olarak EY'nın çoğunluğunun ev içinde ve elektrik prizi ile temas ve veya prize yabancı cisim veya parmak sokma sonucu olduğunu göstermiş̧ir (12-14). Çalışma grubumuzda istatistiksel anlamlı fark bulunmasa da okul öncesi dönemle okul ve ergenlik dönemine doğru prizlere ilginin azaldığı dikkat çekicidir. Bu sonuç okul öncesi dönem çocuğunun çevreyi tanıma konusundaki merak ve heyecanı ile açıklanabilir. Elektrikli aletler ile yaralanma ise en sık 10 yaş üstü grupta görülmüsstür. Bu farklılık bu yaş grubundaki çocukların ev aletlerini kendi başlarına kullanabilmeleri ile açıklanabilir. Çocuklarda elektrik kablosu ile yaralanmanın elektrik kaynağı olarak prizden sonra ikinci sırada olduğu görülmüştür. EY'nin özellikle okul çağı ve ergenlik döneminde en sık açıkta bırakılan kablo ile olması dikkat çekmiştir. Bu kabloların çoğunluğu ise tablet, telefon, bilgisayar kabloları olup artık bu aletlerin çocukların günlük hayatlarının bir parçası olmaları ve çocukların şarj kablolarını dikkatsizce kullanmaları bu sonuca neden olmuş olabilir.

EY yaralanmanın ciddiyetini belirlemek için evlerde kullanılan düşük voltajlı $(<1000 \mathrm{~V})$, yüksek voltajlı $(\geq 1000 \mathrm{~V})$ elektrik akımı ve yıldırım çarpması olarak sıniflandırılır (1).

$\mathrm{Bu}$ çalışmada EY'nın çoğunluğunun düşük voltajlı elektrik kaynağı ile gerçekleştiği ve istatiksel olarak anlamlı fark bulunmasa da yaş arttıkça yüksek voltajlı yaralanmaların daha sık olduğu görülmüştür. Bu sonuç literatürde pediatrik EY ile ilgili diğer çalışmaların sonuçları ile uyumludur (14-16).

EY'de cilt yanıkları çoğunlukla akımın girdiği ve çıktığı yerde cilt üzerinde görülür. Yanıklar çoğunlukla yüzeyel olmakla beraber hafif yaralanmalarda dahi cildin akıma direncini azaltan 1slaklık gibi durumlarda tam kat yanıklar ve doku hasarı oluşabilir. Dolayısıyla ciltte görülen küçük yanıklar olası derin doku hasarını gizleyebilir (10). Yani elektrik akımının giriş ve çıkış lezyonları iç hasar için zayıf belirleyicilerdir (13). Çalışmamızda milimetrik boyutlarda çoğunluğu el ve parmaklarda olan giriş lezyonlarının hepsi birinci derece yanık olup ileri tedavi gerektirmemiştir. Sadece bir hastamızda saptadığımız elektrik kablosunu 1sırmaya bağlı ağız mukozasında yanık dahi ileri müdahale gerektirmemişti. Galnstein ve ark. (16) çalışmalarında hastalarının \%22 kadarına eksizyon ve greftleme ve 2 hastalarına da fasiyotomi uyguladıklar1nı bildirmişlerdir. Çalışmamızın sonucu ülkemizde Oğuz ve ark. (14) nın pediatrik yaş grubunda yaptıkları çalışmanın sonuçları ile uyumludur. Bunun nedeni çalışma serimizi, çoğunluğu düşük voltajlı ev içi yaralanmaları olan ve elektrik kaynağı ile kısa süreli teması olan hastaların oluşturması olabilir. Ayrıca direk akım vücutta birçok dokuda termal enerjiye dönüşüp derin yanıklar meydana getirirken evlerde kullanılan alternatif akım daha çok kaslarda kasılmaya neden olur (17). Çalışma grubumuzda sadece bir hastada kasılma ve nöbet görülmüştür. $\mathrm{Bu}$ olgumuz yüksek voltajlı elektrik direği ile temas sonrası olay yerinde kasılma ve sonrası kardiyak arrest nedeniyle tarafımıza getirilen dokuz yaşında erkek hastaydı.

Sinir sistemi, iskelet ve kalp kası ve nemli ciltte elektrik akımına direnç daha düşüktür (17). Hastalarımızın sadece \%5,4'ünde olay anında çok kısa süreli bilinç kaybı görülmüştür. Bu hastaların yarısının düşük voltajlı alternatif akım diğer yarısının ise yüksek voltajlı akım ile 
yaralandığg görülmüştür. Erişkinlerde santral sinir sistemi yaralanmaları daha yüksek oranda bildirilmektedir (15). $\mathrm{Bu}$ durum erişkinlerin maruz kaldığı elektrik akımının daha yoğun ve vücutla temas etme süresinin daha uzun olması ile açıklanabilir.

Hem düşük hem de yüksek voltajlı elektrik çarpmalarında firlatılmaya bağlı olarak baş, boyun, omurga yaralanmaları da sıklıkla görülebilir (10). Bu nedenle hastaların olası travma bulguları açısından dikkatli değerlendirilmeleri gerekebilir. Fırlatılma öyküsü alınan dört hastamızda yumuşak doku zedelenmesi dışında ciddi travma bulgusuna rastlanmadi.

Kardiyak etkilenme EY' nın en ciddi ve ölümcül etkisidir. Kalp diğer organlara göre elektrik akımından en sık etkilenen organdır. Çünkü hem merkezde bulunması (elektrik akımı elden ele veya baştan ayağa geçişlerde kalbe ulaşır) hem de kan damarlarının direnci daha düşük olduğu için iletiyi direk kalbe ulaştırmasından dolay1 olası ölümcül aritmilere açıktır (18). Sinüs taşikardisi ve erken ventriküler vurular sık görülmekle beraber daha ciddi asistol ve ventriküler fibrilasyon da oluşabilir. Bazı yazarlar özellikle düşük voltajlı EY sonrası kardiyak monitörizayonu önerirken $(19,20)$ bazıları ise başvuru anında EKG normal ve bilinç değişikliği yok ise, gecikmiş disritmilerin olmayacağını dolayısıyla 24 saat monitörizasyonun gereksiz olduğunu öne sürmektedirler $(6,21$, 22). Yüksek voltajlı yaralanmalar için de benzer sonuçları bildirmişlerdir. Çalışmamızda başvuru anında sadece iki hastada EKG anormal olup bu hastalardan biri olay anında kardiyak arrest nedeniyle canlandırma uygulanıp tarafımıza getirilen hasta, diğeri ise sinüs bradikardisi nedeniyle acil serviste monitörize izlenip bulguları düzelen hastadır. Diğer tüm hastaların başvuru anında bilinçleri açık ve EKG bulguları sinüs ritmi idi. Yine de hastalarımızın yarıdan fazlası 4-24 saat acil gözlem odasında kardiyak monitörizasyon ile izlenmiş olup hiçbirinde gecikmiş disritmiye rastlanmamıştır. Yüksek voltajlı yaralanmalarda monitörle izlem süresi konusunda belli bir standart bulunmamakla beraber genellikle kabul edilen görüş 24 saat izlem veya başvuru anında aritmisi olanlarda aritmi bulguları düzeldikten sonra 24 saat izlem şeklindedir.

EY de kardiyak iskeminin belirlenmesinde CK-MB spesifik değildir (18). Miyokard hasarı tanısında CKMB'nin rolü hala tartışmalıdır $(6,24)$. İskelet kası hasarına bağlı CK-MB düzeylerinde artış en erken 12 saatten sonra görülürken miyokard iskemisindeki artış hemen hasar sonrası görülmektedir (18). Bu çalışmada ise başvuruda CK-MB yüksekliği (3 hastada 10-12 kat artış) sekiz hastada bulunmuştur. Bu hastaların aynı zamanda CK düzeylerinin de 2000 IU/L üzerinde olduğu gözlenmiştir. Artmış CK-MB ve CK düzeyleri gerek acil servis izlemi gerekse servis yatış izlemlerinde hiçbir klinik bulgu veya disritmi gelişmeden normal seviyelere gerilemiştir. Kim SH ve ark. çalışmalarında yüksek voltajlı EY olan ancak ölümcül aritmi ve arrest gelişmeyen olgularda Troponin I düzeylerinin prognostik değerinin olmadığını göstermişlerdir (24). Çalışmamızda yüksek voltajlı EY nedeniyle kardiyak arrest gelişen olgumuz dahil tüm hastaların Troponin I düzeyleri normal olarak bulunmuştur. $\mathrm{Bu}$ sonuç başvuruda disritmi ve yakınması olmayan düşük voltajlı elektrik akımına maruz kalan hastalarda rutin Troponin I testi yapılmasına gerek olmadığını düşündürmüştür.

Yüksek voltajlı EY veya yıldırım çarpmaları sonras1 rabdomyoliz gelişimine bağlı akut böbrek yetmezliği oluşabilir. Özellikle CK değerlerinin 1000 IU/L üzerinde olması rabdomyolizi anlamlı kılmaktadır (25). Hastalarımızın tamamına elektrik akım gücü dikkate alınmaksızın başvuru anında böbrek fonksiyon testleri yapılmış olduğu görüldü. Hastalarımızın hiçbirinde (CK değerleri 1000 IU/L üzerinde olan hastalar dahil) akut böbrek yetmezliği tablosu gerek başvuru anında gerekse izlemde gözlenmemiştir. Ayrıca olası iç organ yaralanması açısından tüm hastalardan istenen karaciğer fonksiyon testlerinin de normal olduğu saptanmıştır. Dolayısıyla özellikle düşük voltajlı ve kısa süreli EY'na maruz kalan ve doku hasarına ait klinik bulgu ve yakınması olmayan hastalarda böbrek ve karaciğer fonksiyon testlerinin yapılmasının gerekmeyeceği düşüncesindeyiz.

Cander ve ark. (11) erişkin hasta grubunu içeren çalışmalarında EY sonrası akut dönemde sıklıkla doku hasarı veya travmaya sekonder kan lökosit düzeylerinde artış olduğunu bildirmişlerdir. Çalışmamamızda tüm hastalardan tam kan sayımı istenmiş olduğu görüldü. Ancak kan lökosit düzeylerinin normal değerleri yaş ile değiştiğinden yaş grupları arasında lökosit düzeyleri açısından anlamlı fark bulunmaksızın tüm hastaların lökosit düzeylerinin normal olduğu görülmüştür. Aksoy'un (26) çalışmasında, deri üzerinde bulunan lezyonları, düşük voltaj elektrik akımlarına bağlı ölümlerde tespit etmek kolay değildir. Eğer olayın şahitleri de yok ise kesin ölüm sebebini söyleyebilmek her zaman mümkün olamamaktadır. Bunun yanında ilk anda elektrik çarpması olarak düşünülen, fakat gerçekte başka ölüm sebeplerinin bulunduğu olgular da olabilmektedir.

Yine EY'nın ileri dönemlerinde ileri derecede ve geniş yanıklara ve enfeksiyona bağlı sıvı-elektrolit bozuklukları görülebilir. Hastalarımızın çoğunluğunda derin, geniş yanıkları ve sıvı-elektrolit bozukluğu bulguları olmamalarına rağmen serum elektrolit düzeylerinin test edildiği görülmüştür.

Çalışmamamızın en önemli kısıtlayıcı özelliği geriyedönük çalışma olmasıdır. Dosya verilerinde eksiklikler 
ve bazı hastaların verilerine ulaşılamamıştır. Dolayısıyla çalışma popülasyonumuz özellikle yüksek voltajlı EY olan hasta sayımızın azlığı nedeniyle yaş grupları arasında morbidite ve yatış sürelerine etki eden faktörlerin karşılaştırılması istatistiksel olarak yetersiz kalmıştır. Literatürde pediatrik EY alanındaki çalışmalar az sayıdadır. Bu hastaların yönetimi ve takibi ile ilgili belirlenmiş standart bir protokolün olmaması tetkik ve tedaviyi kişisel ve alışıldık tercihlere bırakmaktadır. Bu konu ile ilgili daha geniş hasta popülasyonu içeren prospektif çalışmalara ihtiyaç vardır.

\section{Sonuç}

Çocuklarda elektrik yaralanmaları çoğunlukla önlenebilir ev içi düşük voltajlı akım ile gerçekleşmiştir. En sık görülen yaralanma prize parmak ya da yabancı cisim sokma şeklinde olduğundan koruyucu kapak ya da çocuk kilidi kullanmak, prizleri çocukların kolaylıkla ulaşamayacağı yükseklikte yerleştirmek gibi basit tedbirler yaralanmaları önemli oranda azaltacaktır. Elektrikli ev aletlerinin ve kablolarının periyodik olarak kontrolü yapılmalıdır. Elektrikle oluşan yaralanmaların sonucu bilinç durumu, kardiyak etkilenme olması, derin doku hasarı olması ve maruz kalınan voltajın yüksekliği gibi birçok faktörden etkilenmektedir. Başvuru anında bilinci açık, derin doku hasarı ve disritmisi olmayan düşük voltajlı elektrik yaralanmalarında ileri incelemeler gerekmeyebilir düşüncesindeyiz.

\section{Kaynaklar}

1. Koumbourlis AC. Electrical injuries. Crit Care Med. 2002; 30 (11): 424-430.

2. Nguyen BH, MacKay M, Bailey B, Klassen TP. Epidemiology of electrical and lightning related deaths and injuries among Canadian children and youth. Inj Prev. 2004; 10 (2): 122-124.

3. Shaw JM, Robson MC. Electrical injuries. In: Herndon DN, editor. Total burncare. London: W.B. Saumders Company; 1996.p.401-407.

4. Casini V. Overview of electrical hazards. In: Worker Deaths by Electrocution: A summary of NIOSH Surveillance and Investigative Findings. Publication No.98-131; Washington, DC: Department of Healthand Human Services; 1998.p.5-8.

5. Arrowsmith J, Usgaocar RP, Dickson WA. Electrica linjury and the frequency of cardiac complications. Burns. 1997; 23(7-8): 576-578.

6. Arnoldo B, Klein M, Gibran NS. Practice guidelines for the management of electrical injuries. J Burn Care Res. 2006; 27(4): 439-447.

7. Petroni T, Moubarak G, Varenne O, Weber S, Duboc D. Do we need to systematically hospitalize electrocuted patients in ICU? Int J Cardiol. 2011; 152(3): 410-411.

8. Claudet I, Maréchal C, Debuisson C, Salanne S. [Risk of arrhythmia and domestic low-voltage electrical injury]. Arch Pediatr. 2010; 17(4): 343-349.

9. Bailey B, Gaudreault P, Thivierge RL. Cardiac monitoring of high-risk patients after an electrical injury: a prospective multicentre study.Emerg Med J. 2007; 24 (5): 348-352.

10. Tekşam Ö, Bayrakçı B. Çevresel Aciller. Türkiye Klinikleri Journal of Surgical Medica 1Sciences. 2007; 3: 112-125.

11. Cander B, Dur A, Koyuncu F, Gül M, Girişgin S. Elektrik Yaralanmalarının Demografik Özellikleri ve Yatış Süresi Üzerine Etkili Faktörler. Akademik Acil Tıp Dergisi. 2010; 2: 72-74.

12. Jain S, Bandi V. Electrical and lightening injuries. Critical care clinics. 1999; 15: 319-331.

13. Rabban JT, Blair JA, Rosen CL, Adler JN, Sheridan RL. Mechanism of pediatric electrical injury. New implications for product safety and injury prevention. Archives of pediatrics and adolescent medicine. 1997; 151: 696-700.

14. Oğuz S, Tuygun N, Akça H, Polat E, Karacan C. Elektrik Yaralanması Nedeniyle Acil Servise Getirilen Çocuklarda Klinik Sonucu Etkileyen Faktörler. CAYD 2015; 2: 121-126.

15. Al B, Aldemir M, Güloğlu C, Kara H, Girgin S. Elektrik çarpması sonucu acil servise başvuran hastaların epidemiyolojik özellikleri. Ulus Travma Derg 2006; 12: 135-142.

16. Glatstein MM, Ayalon I, Miller E, Scolnik D. Pediatric electrical burn injuries: experience of a large tertiary care hospital and a review of electrical injury.Pediatr Emerg Care. 2013; 29: 737740.

17. Koumbourlis, Anastassios C. MD. MPH, Electrical injuries from the Division of Critical Care, College of Physicians and Surgeons of Columbia University, Morgan Stanley Children's Hospital of New York Presbyterian. New York: Lippincott Williams Wilkins; 30, 11 2002; 424-S430.

18. Chandra NC, Siu CO, Munster AM. Clinical predictors of myocardial damage after high voltage electrical injury. Crit Care Med. 1990; 18: 293-297.

19. Jensen PJ, Thomsen PE, Bagger JP, Nørgaard A, Baandrup U. Electrical injury causing ventricular arrhythmias. BrHeart J 1987; 57: 279-83.

20. Carleton SC. Cardiac problems associated with electrical injury. Cardiol Clin1995; 13: 263-266.

21. Bailey B, Gaudreault P, Thivierge RL, Turgeon JP. Cardiac monitoring of children with household electrical injuries. Ann Emerg Med 1995; 25: 612-617.

22. Fatovich DM, Lee KY. Household electrics hocks: who should be monitored? Med J Aust 1991; 155: 301-303.

23. Ahrenholz DH, Schubert W, Solem LD. Creatine kinase as a prognostic indicator in electrical injury. Surgery 1988; 104: 741-747.

24. Kim SH, Cho GY, Kim MK, Park WJ, Kim JH, Lim HE et al. Alterations in left ventricular function assessed by twodimensional speckle tracking echocardiography and the clinical utility of cardiac troponin I in survivors of high-voltage electrical injury. Critical care medicine. 2009; 37: 1282-1287.

25. Mannix R, Tan ML, Wright R, Baskin M. Acute pediatric rhabdomyolysis: causes and rates of renal failure. Pediatrics. 2006;118 (5): 2119-2125.

26. Aksoy ME. Elektrik Akımlarının Neden Olduğu Yaralanmalar. Adli Tıp Bülteni 1997; 2(1): 25-34 DOI: https://doi. org/10.17986/blm.199721201 